\title{
Danmarks udenrigspolitiske udfordringer
}

\section{Peter Brückner}

\section{Udfordringen for dansk udenrigstjeneste er en flytning fra den atlantiske til den globale og den europæiske søjle. Det er et spørgsmål om rettidig omhu og om at udnytte de muligheder, som EU's fælles udenrigspolitik giver}

Danmark må nedlægge sit udenrigsministerium og satse på en fælles europæisk udenrigspolitik, skrev to radikale politikere i Politikens kronik den 20. januar 2004.

$\mathrm{Nu}$ ni år senere er udenrigsministeriet endnu ikke blevet afskaffet. I mellemtiden er de to forfattere blevet ministre, Christian Friis Bach udviklingsminister og Martin Lidegaard klima- og energiminister.

I Politiken Debat den 4. februar sidste år, altså efter valget, der bragte $S$, SF og R i regering, skrev Søren Mørch en stort opsat artikel som skåret over Jeppe Åkjær temaet: "Du puslinge-land, som hygger dig i smug, mens hele verden brænder om din vugge.." Med udgangspunkt i en sønderlemmende kritik af Danmarks militære engagementer i Af- ghanistan, Libyen og ud for Somalias kyst fnyser han: "En god del af den politiske opmærksomhed er blevet brændt af på en aktivistisk udenrigspolitik, der er perspektivløs, fordi den er uden sammenhæng med landets og befolkningens faktiske størrelse."

Selvom han ikke havde behøvet at gå så langt som de radikale politikere otte år tidligere, kan man undre sig over, at Søren Mørch fuldstændig overser eksistensen af den nye europæiske dimension i udenrigspolitikken: den fælles europæiske udenrigs- og sikkerhedspolitik (FUSP), der blev yderligere udbygget med Lissabon-traktatens oprettelse af en ny stilling som udenrigsrepræsentant (HR) og etableringen af en fælles udenrigstjeneste (FUT). 
De to indlæg repræsenterer yderpoler i debatten om varetagelsen af Danmarks udenrigspolitiske interesser. Hvorledes har man fra det officielle Danmarks side stillet sig i dette spændingsfelt?

\section{Det formelle udgangspunkt.}

Af Lissabon-traktaten om Den europæiske Union artikel 24 stk. 1 fremgår at: "Unionens kompetence inden for den fælles udenrigs- og sikkerhedspolitik omfatter alle udenrigspolitiske områder samt alle spørgsmål vedrørende Unionens sikkerhed, herunder gradvis udformning af en fælles forsvarspolitik, der kan føre til et fælles forsvar". Og i stk. 3 hedder: "Medlemsstaterne støtter aktivt og uforbeholdent Unionens udenrigs- og sikkerhedspolitik i en ånd af loyalitet og gensidig solidaritet og respekterer Unionens indsats på dette område."

Det vil således ikke være forkert at sige, at EU's udenrigspolitik også er dansk udenrigspolitik (med respekt for forsvarsforbeholdet); dansk udenrigspolitik kan i hvert fald ikke være uforenelig med EU's uden at komme i strid med traktaten. En sådan modstrid er næppe heller tænkelig i praksis. Danmark vil jo også som medlem af EU's Ministerråd have medvirket til at fastlægge de overordnede retningslinjer og til at vedtage afgørelser om Unionens udenrigspolitiske aktioner og holdninger.
Som påpeget af Rasmus Brun Pedersen (RBP) i Udenrigs 1/2011 markerede udenrigsministeriets debatoplæg Kurs mod 2020 - Dansk udenrigspolitik $i$ nyt farvand af 2010 på en række områder et brud med Foghæraens danske aktivisme og derved en (forsigtig) distancering fra dennes betoning af den atlantiske søjle i den danske udenrigspolitik, en kurs, der i 2002-03 førte til et hidtil uhørt brud (især vedr. indsatsen i Irak) med den konsensus, som i store træk har præget dansk udenrigspolitik siden Anden Verdenskrig, og til en særdeles alvorlig splittelse af EUkredsen.

Oplægget markerede en tilbagevenden til et mere traditionelt, multilateralt spor for dansk aktivisme, en flytning fra den atlantiske til den globale og den europæiske søjle i dansk udenrigspolitik. Især argumenteres der overbevisende for vigtigheden af, at EU i 2020 "indtager en naturlig plads som en effektiv og ligeværdig stemme blandt de absolut ledende spillere på den globale scene - til gavn for Europa og for Danmark."

Som forudset af RBP var det let for den ny regeringskoalition at annamme de nye toner i 2020-papiret. Det fremgår første gang af et lidet påagtet fælles S, SF og R-valgoplæg: "En aktiv og ansvarlig udenrigspolitik" af september 2011: "Vi har en klar interesse i at styrke EU's kapacitet til at handle udenrigspolitisk, så USA og Kina ikke alene får lov at be- 
stemme den internationale dagsorden." Tilsvarende toner lyder i det særlige internationale afsnit af regeringsgrundlaget af 3. oktober 2011.

\section{Overdrevne forventninger}

Men som næunt i 2020-oplægget forudsætter det, at EU viser handlekraft i mødet med tidens betydelige udfordringer. Som fremhævet af Poul Skytte Christoffersen (PSC) i hans artikel 'Fælles udenrigstjeneste med fødselsvanskeligheder' (Udenrigs 3. 2011) er der blevet luftet kritik af langsommeligheden i etableringen af FUT og frustration over manglende resultater, en kritik delvist baseret på overdrevne forventninger ifølge PSC. Det kan heller ikke nægtes, at EU-debatten de seneste par år altovervejende har været præget af Eurozone-krisen, og at der har nok ikke været tid og kræfter til at udvikle FUSP/FUT'en. Hertil kommer, at den konservative britiske regering, der kom til magten efter Lissabon-traktatens ikrafttræden, ved flere lejligheder ligefrem har bremset forsøg på at få fut i FUT'en.

Det er rigtigt, at FUSP ser imponerende ud i bredden, der er snart ikke det udenrigspolitiske spørgsmål, som ikke figurerer på spisesedlen. Men der savnes dybde i FUSP'en; EU har endnu ikke levet op til ambitionen om at udvikle en mere gennemtænkt og sammenhængende strategi i EU's forhold til strategi- ske partnere som USA, Kina, Indien, Brasilien, Rusland m.fl. USA's tidligere udenrigsminister, Hillary Clinton, vidste godt, hvilket nummer hun skulle ringe til, men der var (endnu) ikke så meget at tale om med EU's udenrigschef, Catherine Ashton.

Mens vi venter på bedre tider, vil jeg lufte forslag, der bygger videre på RBP's og PSC's redegørelser uden dog at gå helt så langt som de to radikale politikeres udspil.

Som påpeget af PSC har de nye faste formænd for den politiske- og sikkerhedspolitiske komité (PSC) og de underliggende arbejdsgrupper været lydhøre overfor in put fra medlemslandene. Det er efter hans opfattelse gennem indspil i arbejdsgrupper, komiteer og råd, at medlemslandene kan øve indflydelse på udformningen af EU's udenrigspolitik, en indflydelse, der er af større betydning end at sikre sig stillinger for egne diplomater i FUT'en. Jeg er ganske enig med PSC.

1. Det gør derfor ikke så meget, at det går lidt langsomt med at etablere FUSP/FUT'en. Det giver mindre medlemslande som Danmark mulighed for at finde sine fødder, inden de store medlemslande monopoliserer den ny fælles udenrigstjeneste og dens politik. Det kunne give Danmark tid til at skabe oplæg til en europæisk politik, hvor den endnu ikke findes, eller kun er sporadisk opbygget, fx en kohærent, europæisk strategi i forhold til USA og Kina, 
en europæisk politik, som man fra dansk side gerne så den udviklet. Jeg er overbevist om, at der på Asiatisk Plads er medarbejdere, der ville tænke i disse baner.

Det er altså ikke så meget et spørgsmål om varetagelse af snævre danske interesser, men hvorledes man som dansk europæer vil se den politik, der bedst ville tjene Europas og dermed også i et bredere perspektiv danske - interesser. At tænke i større baner, at forestille sig at repræsentere hele EU's befolkning på mere end 500 mio. mennesker på et territorium, der er over 100 gange større end Danmarks, at tage hensyn til et væld af forskelligartede økonomiske interesser. Og samtidig at kunne inddrage alle de nye instrumenter, som man ikke har til rådighed $\mathrm{i}$ den danske udenrigstjeneste, men som findes i EU's værktøjskasse: enheder, der håndterer civil og militær krisestyring, tilgang til langt større pengemidler end nogen medlemsstats nationale udenrigstjeneste osv. Kort sagt, at tænke europæisk og handle globalt. For at parafrasere Søren Mørchs ovenfor citerede ord mod ham selv: en aktivistisk udenrigspolitik, der er perspektivrig, fordi den er i sammenhæng med Europas og dens befolknings størrelse.

Udarbejdelse af en strategi indebærer også prioriteringer, herunder hvilken plads mere værdiprægede interesser, såsom menneskerettigheder og god regeringsførelse, bør have i en strategi i forhold til Kina.
Her vil en dansk diplomat nok have et andet syn end en britisk eller fransk kollega, der måske vil være præget af sit lands fortid som storog kolonimagt.

Endelig kræver en god strategi en samtænkning af andre politikker, hvor andre end HR har det direkte ansvar: handelspolitikken, udviklingspolitik, udvidelses- og nabopolitikken, en opgave C. Ashton åbenbart ikke har viet særlig opmærksomhed.

FUT'en er endnu en lille tjeneste (knap 2000 i løbet af 2013), den kan langtfra selv støbe alle kuglerne til de strategier, der er nødvendige. Den danske udenrigstjeneste har her en enestående chance for at præge udviklingen, hvis vi kender vor besøgelsestid. Og vi behøver ikke gå enegang. Det drejer sig om at skabe alliancer med ligesindede medlemslande, typisk Sverige og Finland, men også Nederlandene og måske Tyskland, der for nylig selv har lanceret et oplæg til europæisk udenrigspolitik. I modsætning til det kommunitære samarbejde har EU-Kommissionen nemlig ikke monopol på at fremlægge forslag vedr. FUSP til beslutning i Ministerrådet.

\section{Interesser mødes}

Hvor kunne man så forestille sig danske oplæg fremlagt til europæisk strategi? Det bør nok i første omgang være på områder, hvor vi har særlige interesser og forudsætnin- 
ger, og hvor vi har noget at byde på $\mathrm{i}$ EU-kredsen. Her kunne nævnes Arktis, hvor tre små nordiske EUlandes interesser mødes med store landes som Ruslands, USA's og Canadas. I stedet for at friholde EU bør vi involvere EU i dette område, hvor så store interesser - og stormagter - er til stede. Et sådant EUoplæg ville ikke udelukke et nordisk forarbejde, der også inddrager de andre nordiske Arktis-lande Island og Norge. Tværtimod.

Et andet område af mere tematisk art er udviklingsministerens oplæg til en rettighedsbaseret tilgang til udviklingsbistand. Danmark er stadig en respekteret donor-stormagt, og vi har noget at tilbyde de andre EU-partnere. Det kunne være både i Danmarks og EU's interesse at tænke denne tilgang ind i en samlet EUramme.

Endelig kunne man forestille sig et oplæg til EU-strategi om fredsbevarende/-skabende operationer.

Med forsvarsforbeholdet in mente kan det lyde lidt paradoksalt, men vi må tænke på sigt på den dag, hvor den allerede eksisterende politiske enighed om ophævelse af dette forbehold kan virkeliggøres. Danmark er nemlig sammen med EU-partnerne Sverige, Finland og Nederlandene blandt de lande, der i EU-kredsen har de historisk længste og mest vidtfavnende erfaringer vedr. brug af fredsbevarende/skabende operationer. Efter at SHIRBRIG har måttet opgives, kunne der vel tænkes at være en dansk interesse i at få et europæisk projekt op at stå.

2. Selvom det som næunt er vigtigere at præge udformningen af FUSP'en gennem deltagelse i det forberedende arbejde, er det stadig af væsentlig betydning at få dygtige danskere ansat i FUT'en. Den vedtagne ordning giver mulighed for ansættelse i en periode på fire år med mulighed for forlængelse.

\section{Dansk kandidatmangel}

Trods arbejdsløshed også inden for de relevante akademiske uddannelser kniber det stærkt med at få mønstret et rimeligt antal danske kandidater - for slet ikke at tale om at få dem ansat i FUT'en. Der er for tiden ansat 40 danskere i FUT'en, heraf 23 AC'er, men få i chefsstillinger. Det svarer til 2,5\% af den samlede stab, en andel der ligger over vor uofficielle 'kvote' på 1,6\%. Hvis man ser på aldersfordelingen, vil den andel om cirka fem år svinde gradvist til $0,8 \%$. Og nyrekruttering af danske diplomater har vist sig vanskelig. Af hidtil 140 anmeldelser er det kun lykkedes at få syv danske diplomater ansat. Ingen af de 357 kandidater, der meldte sig til sidste års adgangsprøve for AC-generalister, bestod. Derfor har europaministeren nu nedsat en analysegruppe, der skal fremsætte anbefalinger med det formål at få flere danskere til at søge og hjælpe dem, der søger, igennem adgangsprøven. 
Udenrigsministeriet har over en årrække på sin hjemmeside opbygget en særlig portal med oplysninger om ansættelsesmuligheder i internationale organisationer samt i EU's institutioner og organer. Disse bestræbelser bør suppleres med en aktiv dansk personalepolitik, der kan gøre det mere attraktivt for egnede kandidater at søge stillinger $\mathrm{i}$ $\mathrm{EU}$, herunder især i FUT'en.

Der kan være mange grunde til den manglende interesse i Danmark, men jeg er sikker på, at den sidste viking ikke er død endnu. Ansættelse i FUT'en bør kædes sammen med en garanti for tilbagegang til tjeneste i Danmark kombineret med en belønning fx i form af forfremmelse el. lign. Der har været gjort forsøg på en sådan personalepolitik siden 1973, men hidtil uden de store resultater.

3. Mønstret af danske ambassader og andre repræsentationer bør anskues mere strategisk. Vi bør fx forlade princippet om at have en dansk ambassade i alle de andre EU-landes hovedstæder. Valget af lokaliteter, hvor vi bør være aktivt til stede, bør afgøres af en langsigtet, gennemtænkt strategi, herunder hvilke af de ny EU-delegationer, som vi kan og bør samarbejde særligt nært med. At anlægge en mere europæisk dimension i tænkningen på Asiatisk Plads betyder ikke, at vor udenrigstjeneste helt kan afskaffes - i hvert fald ikke endnu som foreslået af de to radikale politikere.
For det første vil arbejdet med eksportfremme og tiltrækning af udenlandske investeringer mv., der over de seneste årtier har indtaget en stadig større plads i udenrigstjenestens arbejde, fortsat være en national opgave.

Det samme gælder konsulære opgaver, idet der dog er forudset et nærmere samarbejde mellem EUlandenes repræsentationer om beskyttelse af unionsborgere. Hertil kommer kulturelt samarbejde og rene bilaterale sager mellem Danmark og det pågældende tredjeland, herunder også EU-lande.

Og vi vil endnu have en dansk udviklingspolitik, forhåbentlig forvaltet i et stadig tættere samarbejde med de andre bi- og multilaterale donorer i de lande og sektorer, hvor vi er aktive. EU er nu verdens største enkeltdonor af udviklingsbistand.

\section{Aktiv dansk indsats}

I de lande, som Danmark har en strategisk interesse $i$, vil der i lang tid fremover være behov for endog en meget aktiv dansk indsats. Det lokale samarbejde mellem EU-landenes repræsentationer vil i en uoverskuelig overgangsperiode kunne have en overordentlig stor betydning ved udformningen af EU's strategier ift. det pågældende land eller den pågældende region, $\mathrm{fx}$ gennem de såkaldte HOMS, Head of Mission rapporter, landeanalyser, der kan give et overmåde væsentligt input til 
FUSP-strategiarbejdet i Bruxelles.

Omvendt kan tilstedeværelsen af kompetente EU-ambassader give anledning til at reducere de danske ressourcer i de pågældende lande.

4. Udenrigsministeriets koordinerende rolle i den danske EU-beslutningsprocedure bør genovervejes. Er denne rolle i dag en udenrigspolitisk opgave? Nej, og derfor bør den også flyttes over i et europaministerium (nu har vi jo fået en europaminister) eller til statsministeriet. Udenrigstjenesten bør koncentrere sig om det, den fagligt er særlig god til, og som ingen andre danske myndigheder har kompetence til: at varetage Danmarks udenrigspolitiske interesser, i denne artikel set i en bredere sammenhæng som aktiv deltagelse i en europæisk udenrigspolitisk interessevaretagelse.

2012 blev endnu et annus horribilis for EU præget af eurozonekrisen, stigende indadvendthed, selvkritik, pessimisme og tilbageholdenhed. Jeg fornemmer endog en stigende skepsis om selve EU-projektet ikke blot i Storbritannien (forslag vedr. folkeafstemning om EU i 2015 ), men også i Danmark hos tidligere faste EU-støttepartier. Reaktionen på Venstres landsmøde på Jens Rohdes og Erik Boels debatoplæg i kronik i Jyllandsposten af 17. november 2012 samt diskussionerne i anledning af et nyt EU-oplæg på de konservatives landsmøde i efteråret tyder ikke blot på en stigende skepsis, men vidner også om en foruroli- gende passivitet over for behovet for at diskutere de helt væsentlige emner, som bl.a. var indeholdt i JP-kronikken, herunder om styrkelse af EU's rolle på verdensscenen.

Tidspunktet er derfor måske ikke så velvalgt til fremsættelse af forslag om at give dansk udenrigspolitisk tænkning en ægte europæisk dimension.

Heldigvis har der været opmuntrende læsning, herunder af den artikel som Nicolai Wammen og tidligere britiske udenrigsminister David Miliband skrev i International Herald Tribune den 10. december sidste år, dagen, hvor EU fik overrakt Nobels fredspris. Tilsvarende toner lød i IHT den 1-2. september, 2012 fra Timothy Garton Ash, der argumenterede overbevisende for en 'genuinely common foreign policy', som Kina, USA og Rusland ville tage alvorligt.

Hvis man ser på udviklingen siden indførelsen i 1970'erne af Det europæiske Politiske Samarbejde (EPS), spiren til FUSP'en, og udviklingen i EF's eksterne relationer, der blev gift med EPS i Maastricht-traktaten i 1992, kan man konstatere, at tendensen over tid - med tilbagefald af og til - er gået i retning af stadig større fodslag i de udenrigspolitiske holdninger mellem EU-landene. Og det endda samtidig med en forøgelse af medlemstallet fra ni i 1970 'erne til 27 i dag. Der er ingen grund til at nære seriøs tvivl om FUSP'ens overlevelsesevne på sigt, selvom især faste medlemmer af FN's Sikkerheds- 
råd som Storbritannien og Frankrig har svært ved at slippe tøjlerne.

Det vil derfor være udtryk for særdeles rettidig omhu, om man fra dansk side tager en uundgåelig udvikling i opløbet, og forsøger at øve størst mulig indflydelse på FUSP'ens nærmere indhold med henblik på. at styrke varetagelsen af EU's, og dermed også Danmarks interesser på den globale scene. Intet enkelt EU-land er i stand til effektivt at tackle de globale udfordringer alene. Som Uffe Østergaard i Udenrigs
3/2011 citerede fra en tidligere EUkommissionsformand: "EU består kun af små lande - forskellen er blot, at nogle af dem ikke har opdaget det endnu."

Peter Brückner var tidl. juridisk rådgiver i EF's Ministerråds generalsekretariat med sarligt ansvar udenrigsrelationer. Fra 1978-81 ansvar for Europaisk Politisk Samarbejde (EPS). Har skrevet bog om EF's udenrigsrelationer og flere artikler om EPS. Ambassadør i Sydafrika, Japan og ved OECD og UNESCO $i$ Paris. 